\title{
Misunderstandings of Communicative Language Teaching
}

\author{
Wen $\mathrm{Wu}$ \\ Division of International Cooperation and Exchanges, Yangtze Normal University \\ 98 Julong Rd. Lidu, Fuling District, Chongqing 408100, China \\ Tel: 1-778-990-8598Ｅmail: wuwenjay2006@gmail.com
}

\begin{abstract}
Although Communicative Language Teaching is accepted by many English teachers in China as one of the most effective approach in English language teaching, there are still a number of misunderstandings about it. By comparing Johnstone; Sato and Kleinsasser and Thompson as well as Spada, this article focuses on four of the main misunderstandings, which are commonly held by the language teachers and researchers.

Keywords: CLT, Misunderstanding, Meaning, Learner Error, Learners' L1

Communicative Language Teaching (CLT) is generally regarded as an approach to language teaching. It is based on the theory that the primary function of language use is communication. One of the fundamental principles of CLT is that learners need to engage in meaningful communication to attain communicative fluency in ESL settings. So its primary goal is for learners to develop communicative competence (Hymes, 1971), or simply put, communicative ability. Therefore, many teachers think that CLT emphases the speaking and listening in order to improve their communicative ability by focusing on meaning, and refuses error correction for maintaining the conversation. In this article, the writer tries to analyze the misunderstandings, which are commonly held by the language teachers.
\end{abstract}

\section{CLT means an exclusive focus on meaning}

At present, the most popular misunderstanding of CLT should be that CLT is an approach to foreign language education which focuses on meaning to the exclusion of any attention to language forms. But, with the view of most applied linguistics---especially British applied linguistics, this characterization of CLT is not consistent, because they have recognized the importance of a formal language component with CLT. According to their understanding, CLT should be a language educational approach that was intended to include communication, which was not intended to exclude form. However, many language teachers in China was affected by applied linguists such as Prabhu (1987), who argued that grammar is too complex to be taught, and second language acquisition researchers like Krashen (1982), who claimed that grammar can only be acquired unconsciously through exposure to the target language, so they believe that a special attention should be given to the meaning, not the form.

What does classroom research on L2 learning and teaching have to say about this? Since 1980s, classroom researchers and program evaluators have carried out a great deal of researches on the effectiveness of CLT in many countries. Savignon (1972) did an experimental study to examine the contributions of CLT to L2 learning. Her research investigated the effects of adding a communicative component to university-level audio-lingual classes in French. Comparisons of learners who had received the additional component with those who received either an additional cultural component or further audio-lingual practice revealed that learners in the communicative component performed better on the communicative test than those who in the cultural or audio-lingual groups. Learners in the communicative group also performed at least as well on the linguistic tasks as learners in the other two groups. These results demonstrated the benefits of adding a communicative component to structure-based teaching.

Since Savignon's study, other classroom research has indicated that CLT contributes positively to the L2 learners' fluency and communicative abilities. Furthermore, in some instances (e.g. Canadian French immersion programs), CLT has enabled L2 learners to develop comprehension abilities that parallel those of native speakers (Genesee, 1987). At the same time, observational research in CLT classrooms, particularly those in which no attention is given to language form, has shown that students often fail to reach high levels of development and accuracy in many aspects of language (Harley and Swain, 1984, Spada and Lightbown, 1989). The experimental research results have indicated that the inclusion of form-focused instruction leads to improvement in students' knowledge and their ability to use that knowledge (Norris and Ortega, 2000 and Spada, 1997).

In China, there are many language teachers who practice communicative approach by balance form and meaning via combination Grammar-Translation into their classroom; some other reject the CLT because of this misunderstanding of 
CLT, and they have realized that exclusive focus on meaning will fail to develop students' language competence. But actually, CLT is not conceptualized as an approach that was intended to exclude form but rather one that was intended to include communication.

\section{CLT means no explicit on learner errors}

For teachers, there is an embarrassment for fluency and accuracy, especially when meet learner errors. So another misunderstanding about CLT is that it should not include corrective feedback. This idea was affected by the fact that many teachers have been educated to believe that errors are evidence that the learner is testing hypotheses about the target language and in the process, progress is being made. The assumption is that with sufficient time and opportunities to hear and practice the target language, the learners' errors will eventually be replaced with target-like forms.

While some researchers have argued for the total rejection of any type of corrective feedback (Truscott, 1999), this represents an extreme view and is not typical of how most CLT teachers and researchers view feedback on learner errors (Lyster, 1999). Instead, the type of corrective feedback that is widely encouraged and accepted in CLT is implicit and does not interfere with communication. For example, a particular type of feedback, which is called RECAST, has been observed to occur frequently in CLT classrooms. A recast is the teacher's reformulation of a learner's incorrect utterance while maintaining a focus on meaning: for example, the L2 learner says, "His foots are cold," and the teacher responds by saying, "Yes, his feet are cold---he has stayed outside for a long time!"

The recast serves as corrective feedback by providing the learner with the correct form while at the same time confirming the content of the learner's utterance and continuing with the conversation. There are a number of advantages of recast. First, one can be more confident of gaining the student's attention, since one is talking about topics of interest to the student. There is also a strong likelihood that the student will comprehend at least part of what is being said to them, since lexical items are being reflected back to them from their own utterance. Recasts are thus an effective means of maintaining conversation with very beginning learners. It is not surprising, therefore, that they figure heavily in student-teacher discourse (Brown and Bellugi, 1964; Chouiniard and Clark, 2003). They also figure in a range of theoretical approaches to teacher-learner interaction, including interactional linguistics (Selting and Couper-Kuhlen, 2001) and conversation analysis (Norrick, 1991).

According to Brandl. K (2008), the provision of "error corrective" and "positive" feedback as a fundamental principle of CLT permeates all areas of instruction and constitutes a necessity in support of the learning process. And he suggests teachers use recast for feedback during the teaching.

\section{CLT means listening and speaking practice}

In China, many educators said that, for many learners, the main uses that they are likely to make of the language are oral: getting around in the foreign country if they visit it, talking to visitors from that country, etc. CLT is just for the meet of the learners' needs, therefore, the emphasis of language teaching is likely to be on speaking and listening skills, which is the focus of L2 instruction under the guidance of audio-lingua method. However, from the beginning, many CLT researchers agreed that one of the basic tenets of CLT was that linguistics skills and communicative abilities should not be treated in isolation from each other (Savignon, 1997). In his discussion of the importance of attention to discourse in CLT, Widdowson(1978) claims: "What the learners need to know how to do is to compose in the act of writing, comprehend in the act of reading, and to learn techniques of reading by writing and techniques of writing by reading" (P. 144). Influenced by Widdowson and others, CLT materials writers have produced reading texts that are much more varied in terms of their content than in those typical of traditional structure-base instruction. Also, texts that have been specifically designed to meet the needs of particular groups of L2 readers (e.g. English for academic /scientific purposes) are abundant in CLT pedagogical libraries. Furthermore, the experiences that L2 learners needs to keep in mind the relevant contextual and social factors contributing to their comprehension (i.e. listening and reading) and production (i.e. speaking and writing) has always been part of the fundamental principles and practices of CLT. A glance at recent mainstream textbooks in China will immediately find that they are also likely to be reading and writing a more varied range of texts than those in more traditional classes. CLT involves encouraging learners to take part in---and reflect on---communication in as many different contexts as possible (and as many as necessary, not only for their future language-using needs, but also for their present language-learning needs).

\section{CLT means avoidance of the learners' $L 1$}

Though the teaching methods popular in the $20^{\text {th }}$ century differed in many ways, they nearly all tried to avoid using the students' first language (L1) in the classroom. The only exceptions were the Grammar-translation Method, which still seems to keep going despite the serious critics and the short-lived Reading Method in US in the 1930s. But everything else from the Direct Method to the Audio-lingual Method to Communicative Language Teaching insists that the less the L1 is used in the classroom, the better the teaching. In the early days the L1 was explicitly rejected, going back to the language teaching revolutions of the late $19^{\text {th }}$ century. Later the L1was seldom mentioned as a possibility, apart from occasional advise about how to avoid it; for example, in task-based learning (one form of CLT) for beginners 'DON'T 
ban mother tongue use but encourage attempts to use the target language' (Willis, 1996,P.130). This suggests either the mother tongue does not play an important role in foreign language teaching or the issue of native language use does not exist in the classroom, since most of them are native speaker of English accustomed to working with multilingual group of students.

The argument against the use of L1 in L2 classrooms is obvious: Learners need as much exposure to the target language as they can get in order to become successful learners of that language. This is supported by considerable evidence that both the quantity and quality of target language input are crucial factors in L2 learning (Gass, 1997; Lightbown, 1991). However, in a recent paper that calls for a re-examination of the restrictions on L1 use in L2 classrooms, Cook (2001) argues that while "no one will quarrel with providing models of real language use for the students... (this is) not necessarily incompatible with L1 use in the classroom" (P. 409).

Sensible arguments can be made for the principled use of L1 in L2 classrooms and there is theoretical, empirical, and pedagogical support for it. For example, the belief that first and second languages exist in separate compartments in the mind and therefore should be kept separate in the classroom has not received empirical support. Neurolinguistics (Obler, 1982), psycholinguistic (Harris, 1992), and linguistic (Romaine, 1989) research has shown that knowledge overlap of the basic components of linguistic information from two languages as common underlying proficiency. The notion of a common underlying proficiency has pointed to important benefits of L1 knowledge and use particularly for minority language children in bilingual education programs (Ramirez, 1992). This work has shown that there is significant transfer of conceptual knowledge and skills across languages. In a recent study of the L2 development of French immersion students engaged in collaborative tasks, Swain and Lapkin (2002) report that the use of the L1 enabled students to continue with the task and in the process to move forward in achieving their linguistic goals. In addition, Turnbull (2001) points to several pedagogic benefits of L1 use in the classroom (e.g. saving time, providing clearer and more concise explanation).

Despite the evidence that the L1 can have an important and positive role to play in L2 learning, CLT researchers mentioned that we must be careful about exactly how much L1 use is productive. And some CLT researchers suggest that languages teachers present in the classroom must base on the comprehension of the students, otherwise no learning can occur. A teacher's goal needs to be to find the right balance between the use of L1 and L2, which makes sure students understand and at the same time maximizes the use of the target language.

Since the introduction of Communicative Language Teaching in the 1970s, there have been different definitions and interpretations of the communicative approach to foreign language education. So, it has no surprise that there are a lot of misunderstandings of CLT. These four misunderstandings are most commonly held by the language teachers and researchers.

\section{References}

Brandl, K (2008). Communicative Language Teaching in Action, New Jersey: Pearson Prentice Hall.

Brown, R. and Bellugi, U. (1964). Three processes in the child's acquisition of syntax. Harvard Educational Review 34 , 133-51.

Brumfit, C. J. (1984). Communicative methodology in language teaching: The Roles of Fluency and Accuracy. Cambridge: Cambridge University Press.

Chouinard, M. M. \& Clark, E. V (2003). Adult reformulations of child errors as negative evidence. Journal of Child Language 30, 637-69.

Cook, V. (2001). Using the first language in the classroom. Canadian Modern Language Review. 57, 02-423.

Gass, S. (1997). Input, interaction and the second language learne. Mahwah, NJ. Lawrence Erlbaum Associates.

Genesee, F. (1987). Learning through two languages. Rowley, Mass: Newbury House.

Harley, B. \& Swain, M. (1984). The interlanguage of immersion students and its implications for second language teaching. In A. Davies, C. Criper, \& A. Howatt (Eds.), Interlanguage (pp. 291-311). Edinburgh: Edinburgh University Press.

Harris, R. J. (Ed.) (1992). Cognitive processing in bilinguals. Amsterdam: North-Holland.

Hymes, D. (1971). On Communicative Competence. Philadelphia: University of Pennsylvania Press.

Johnstone, R. (1999). Research on language teaching and learning: 1999. Language Teaching, 23, 165-189.

Krashen, S. (1988). The Input Hypothesis: Issues and Implications. London: Longman.

Lightbown, P. M. (1991). Getting quality input in the second/foreign language classroom. In C. Kramsch \& S. McConnell-Ginet (Eds.). Text and context: Cross-disciplinary perspectives on language study (pp.187-197). Lexington, Mass: D. C. Heath and Company. 
Lyster, R. (1999). Recasts, repetition, and ambiguity in L2 classroom discourse. Studies in Second Language Acquisition, 20, 51-81.

Norrick, N. R. (1991). On the organization of corrective exchanges in conversation. Journal of Pragmatics, 16, 59-83.

Norris, J. M. \& Ortega, L. (2000). Effectiveness of L2 instruction: A research synthesis and quantitative meta-analysis. Language Learning, 50, 417-528.

Obler, L. (1982). The parsimonious bilingual. In L, K. Obler \& L, Menn (Eds.), Exceptional language and linguistics (pp. 339-346). San Diego, CA: Academic Press.

Ramirez. (1992). Executive summary. Bilingual Research Journal, 16, 1-62.

Romaine, S. (1989). Bilingualism. Oxford: Blackwell.

Sato, K. \& Kleinsasser, R. C. (1999). Communicative language teaching (CLT): Practical understanding. The Modern Language Journal, 83, 494-517.

Savignon, S. (1972). Communicative competence: An experiment in foreign language teaching. Philadelphia: Center for Curriculum Development.

Savignon, S. (1997). Communicative competence: Theory and classroom practice (2 ${ }^{\text {nd }}$ ed.). New York: McGrawHill.

Selting, M. and Couper-Kuhlen, E. (editors) 2001: Studies in interactional linguistics. Amsterdam: John Benjamins.

Spada, N. (1997). Form-focused instruction and second language acquisition: A review of classroom and laboratory research. Language Teaching, 30, 73-87.

Spada, N. \& Lightbown, P. M. (1989). Intensive ESL programs in Quebec primary schools. TESL Canada Journal, 7 , 11-32.

Spada, N. (2007). Communicative Language Teaching: Current Status and Future Prospects. In Jessner, U. and Cenos, J. (ed.) International Hand Book of English Language Teaching （Part I). New York: Springer.

Swain, M. \& Lapkin, S. (2002). Talking it through: Two French immersion learners' response to reformulation. International Journal of Educational Research, 37, 285-304.

Thompson, G. (1996). Some misconceptions about communicative language teaching. ELT Journal, 50, 9-15.

Truscott, J. (1999). What's wrong with oral grammar correction? Canadian Modem Language Review, 55, 437-456.

Turnbull, M. (2001). There is a role for the L1 in second and foreign language teaching, but... Canadian Modern Language Review, 57, 531-540.

Widdowson, H. G. (1978). Teaching language as communication. Oxford: Oxford University Press.

Willis, J. (1996), A Framework for Task-based Learning. Harlow: Longman. 